\title{
Uncommon but potential life-threatening complication after tonsillectomy: post-tonsillectomy cervicofacial surgical emphysema
}

\author{
Ashraf Nabeel Mahmood
}

ENT, Heart of England NHS Foundation Trust, Birmingham, UK

\section{Correspondence to} ashrafmahmood@yahoo.com

Accepted 1 February 2018 Mr. Ashraf Nabeel Mahmood,

\section{DESCRIPTION}

A 40-year-old woman underwent a tonsillectomy due to recurrent tonsillitis and previous left peritonsillar abscess. During the surgery, it was noticed that the leftside tonsil was adherent to the tonsillar fossa. Intubation, surgery and the recovery period were uneventful. The next morning, the patient developed left-side facial and neck swelling extending to the midline. Clinical examination showed non-tender soft swelling and crepitus with no shortness of breath nor trismus. Neck X-rays confirmed the diagnosis of surgical emphysema (figure 1A,B). Consequently, the patient was kept nothing by mouth and fed through a nasogastric tube. Intravenous antibiotics and steroids were initiated along with instructions to avoid straining or coughing. Swelling improved gradually and disappeared completely on the fourth postoperative day when she was started on clear oral fluids. With no continuing clinical concerns, she was upgraded to full diet and discharged with follow-up, which showed normal healing and postoperative course.

Patients with recurrent tonsillitis and previous peritonsillar abscess can develop fibrosis and adhesions of the tonsillar tissue to the fossa and underlying muscular layers as part of the healing process, which in turn can increase the risk of postoperative complications. ${ }^{12}$ In our case, the most likely pathogenesis of this rare complication is the deep dissection into the tonsillar fossa and the superior pharyngeal constrictor muscle fibres because of pre-existing adhesions. This can create a defect through which air leaks to subcutaneous tissue planes and can extend to different cervical spaces including the parapharyngeal, retropharyngeal, pleural and mediastinal spaces, which can cause potential life-threatening complications such as airway obstruction and pneumothorax. ${ }^{23}$ In other reported cases, emphysema developed due to traumatic intubation to the tonsillar area. ${ }^{13}$
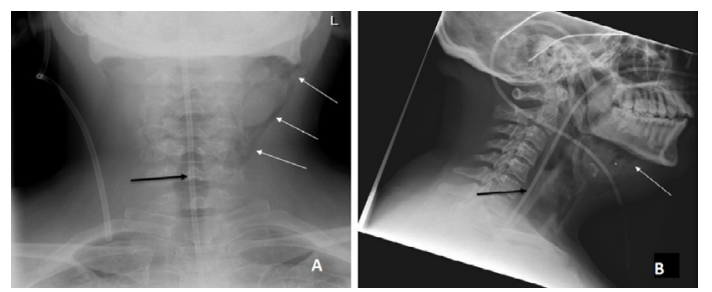

Figure 1 (A) X-rays showing extensive air in the left side of the neck (white arrows) and (B) extensive air in the left submandibular area (white arrow). Nasogastric tube in situ (black arrow).

\section{Learning points}

- Careful dissection is essential to prevent complications during tonsillectomy, especially in adults with history of peritonsillar abscess.

- Life-threatening complications of posttonsillectomy emphysema, such as airway obstruction, pneumothorax and pneumomediastinum, can be ruled out by clinical examination and radiological investigation like X-ray, CT scan and contrast radiography.

- The mainstay treatment in majority of the cases of post-tonsillectomy emphysema is conservative management, as it is a self-limiting pathology. Although in some cases with lifethreatening complications, surgical intervention is needed.

The management of post-tonsillectomy emphysema in the vast majority of the cases is conservative, as it will cause no life-threatening symptoms and resolves spontaneously. This includes closed airway observation, administration of antibiotics, keeping the patient nothing by mouth with an alternative route for feeding and avoidance of any activities that can increase the intrapharyngeal airway pressure. In more severe cases, when emphysema compromises the airway, tracheostomy will be needed. If there is a clinically detectable defect with symptoms that are not responding to conservative measures, direct surgical repair of the tear might be another option. ${ }^{13}$

Contributors ANM is the only author for this case report. ANM did the data collection and literature review, wrote the article and got the patient consent.

Competing interests None declared.

Patient consent Obtained.

Provenance and peer review Not commissioned; externally peer reviewed.

(C) BMJ Publishing Group Ltd (unless otherwise stated in the text of the article) 2018. All rights reserved. No commercial use is permitted unless otherwise expressly granted.

\section{REFERENCES}

1 Bizaki A, Kääriäinen J, Harju T, et al. Facial subcutaneous emphysema after tonsillectomy. Head Face Med 2014;10:11.

Case Rep Published Online

First: [please include Day

Month Year]. doi:10.1136/ bcr-2017-223964
2 Yelnoorkar S, Issing W. Cervicofacial surgical emphysema following tonsillectomy. Case Rep Otolaryngol 2014;2014:1-2.

3 Jabr A I, Alharethy S. Cervicofacial subcutaneous emphysema a rare complication of tonsillectomy. Sciencedirect 2013;15:49-51. 
Copyright 2018 BMJ Publishing Group. All rights reserved. For permission to reuse any of this content visit http://group.bmj.com/group/rights-licensing/permissions.

BMJ Case Report Fellows may re-use this article for personal use and teaching without any further permission.

Become a Fellow of BMJ Case Reports today and you can:

- Submit as many cases as you like

- Enjoy fast sympathetic peer review and rapid publication of accepted articles

Access all the published articles

- Re-use any of the published material for personal use and teaching without further permission

For information on Institutional Fellowships contact consortiasales@bmjgroup.com

Visit casereports.bmj.com for more articles like this and to become a Fellow 